\title{
Violência entre pares na adolescência: Um estudo com estudantes no início e no final do 3. ciclo do ensino básico
}

\author{
Ana Cristina Rosário ${ }^{1}$, Adelinda Candeias ${ }^{1}$ \& Madalena Melo ${ }^{1,2}$ \\ ${ }^{1}$ Universidade de Évora \\ ${ }^{2}$ CIDEHUS- UÉ
}

\begin{abstract}
Resumo: Este estudo propõe-se caraterizar comportamentos de violência entre pares, em função do nível de escolaridade, género e variáveis socioafetivas. Os participantes incluem uma amostra de 80 estudantes do 3. ciclo do ensino básico (7.. - 9.. anos), avaliados com o QEVE, em dois momentos (7. e 9.‥ anos). Os resultados demonstram que: i) as condutas de vitimação e agressão mais frequentes são a exclusão social e a agressão verbal; ii) a taxa de vitimação diminui do 7.- para o 9.ำ ano, enquanto a taxa de agressão mantém-se estável; iii) os rapazes encontram-se mais envolvidos em situações de bullying físico do que as raparigas; iv) o sentimento face à escola (i.e., gostar da escola) e a perceção de ter amigos revelam-se aspetos protetores especialmente importantes das condutas de vitimação e agressão entre os alunos do nível de escolaridade mais baixo. Estes resultados sugerem uma intervenção educativa diferenciada e orientada para a literacia socioemocional, destacando o papel dos pares na prevenção da violência escolar.
\end{abstract}

\section{Palavras-chave: Agressão; Vitimação; Bullying; Escola; Adolescentes.}

Peer violence in adolescence: $A$ study with students in the beginning in the end or the $3^{\text {rd }}$ cicle of basic education: This study aims at characterizing behaviours of peer violence, according to school level, gender and socio affective variables. Participants include a sample of 80 students attending the $3^{\text {rd }}$ level of elementary education (grades $7-9$ ), which were evaluated with QEVE, in two distinct moments: $7^{\text {th }}$ and $9^{\text {th }}$ grades. The results show that: $\left.i\right)$ the most frequent conducts of victimization and aggression are social exclusion and verbal aggression; ii) the victimization rates decrease from 7 th to 9 th grade although the aggression rates remain stable; iii) boys find themselves more involved in physical bullying situations than girls; vi) the felling towards school (i.e., school liking) and the perception of having friends are revealed has important protective aspects in victimization and aggression conducts. These results are suggestive of a differential educational intervention, oriented to socioemotional literacy, highlighting the role of peers in prevention of school violence.

Keywords: Aggression; Victimization; Bullying; School; Adolescents.

A violência entre pares - bullying - constitui-se como um fenómeno preocupante em contextos educativos. Nos últimos anos tem-se assistido a um aumento substancial da investigação nesta área, não só porque estamos perante um problema com contornos cada vez mais complexos, mas também porque parece afetar todo o clima escolar (Rose, Nickerson, \& Stormont, 2015; UNESCO, 2017) e deixar marcas profundas nos seus intervenientes (NASEM, 2016).

O termo bullying pode definir-se como um subtipo do comportamento agressivo (Martins \& Silva, 2014), que pretende designar determinadas condutas de vitimação e agressão que ocorrem entre pares, de modo intencional e continuado, em que o abuso perpetrado pelo mais forte sobre o mais fraco, ou o abuso de um grupo sobre uma vítima indefesa parece ser a caraterística mais saliente (Rose et al., 2015).

O bullying manifesta-se através de condutas de distinta natureza (NASEM, 2016), podendo caraterizar-se como: (i) direto e físico, que implica atacar fisicamente outra pessoa, roubar ou danificar os seus pertences; (ii) direto e verbal, que implica chamar nomes, opor-se com uma atitude desafiadora e ameaçar; (iii) indireto, que implica espalhar rumores pejorativos ou isolar socialmente.

A maioria dos estudos sobre o bullying entre pares coloca também em destaque a dimensão grupal deste fenómeno (Rodkin, Espelage, \& Hanish, 2015; Thornberg, 2015), sendo possível identificar diferentes papéis de participação no bullying, nomeadamente: vítimas, agressores, vítimas/agressoras (também designadas por vítimas provocadoras) e observadores (cujo papel pode variar do apoio aos agressores principais - assistentes ou reforçadores, até à ajuda à vítima - defensores, passando pela

${ }^{1}$ Endereço para correspondência: Ana Cristina Rosário, Departamento de Psicologia, Escola de Ciências Sociais da Universidade de Évora. Colégio Pedro da Fonseca, Apartado 94, 7002-554 Évora E-mail: arosario@uevora.pt 